\title{
GENESIS 2:5, 6: WET OR DRY?
}

By DEREK KIDNER

Since there are some words of debatable meaning in these two verses, it will be convenient to discuss these first. Then I will state the problem implied in the title, together with some of the solutions that have been proposed; finally I will suggest an alternative answer.

I. In verse 5 the words עיח denote (if we may judge from other Old Testament passages) bush and herb respectively. The two other occurrences of שיח suggest wild growth of the waste land: Hagar left Ishmael under a to die in the wilderness of Beersheba (Gn. 21:15), and Job depicted homeless wanderers in such a setting ( $\left.\mathrm{Jb} \cdot \mathrm{J}^{0}: 7\right)$. עש is a common word, sometimes used of green growth in general (e.g. Am. 7:2), sometimes of the crops which are edible by man (e.g. Gn. $3: 18)$. The distinction therefore may be between the wild and the cultivated, ${ }^{1}$ or the perennial and the annual, or simply the large and the small; in any case the phrase evidently expresses the totality of growing things. U. Cassuto ${ }^{2}$ however dissents from this, arguing that since $3: 18$ mentions the herb of the field, the other terms in that verse (thorns and thistles) will correspond to the שn our present verse and determine its meaning. To him, 2:5 is stating that the only growths not found in Eden were שיח and the former because it needed rain, the latter because it needed cultivating; and both rain and arable farming were, in his view, consequent on the Fall. Since this rests however on the gratuitous equation of $2: 5$ with $3: 18$ and on the still more precarious assertion that thorns and thistles fail to grow on

I. Possibly as dependent respectively on rain and on man: verse 5 b.

2. A Commentary on the Book of Genesis, Magnes Press, Jerusalem (I96I) I, 102-103. 
land that is watered by inundation, it hardly carries conviction.

The meaning of 7 in verse 6 has to be gathered partly from its predicate, that it 'watered the whole face of the ground', partly from Job $36: 27$ ('he draweth up the drops of water which distil in rain 'לאדו') and partly from comparative philology. In Job 36:27 the usual rendering of mist' or 'vapour' is a guess from the context of rain and clouds. 'Flood' or 'sea' however would suit the context equally, as in M. H. Pope's translation: 'He draws the waterdrops that distil rain from the flood' (treating $x$ as a modification of Accadian $e d \hat{u}$, and the preposition ל as meaning 'from' ( $c f . \mathrm{RV})$, as in Ugaritic). ${ }^{3}$

This leads into the philological field, where there are two main suggestions. Albright in 1938 and $1939^{4}$ (but also Dhorme in $1907^{5}$ and Sachse in $\left.1921^{6}\right)$ derived $7 x$ from the Sumero-Accadian $I d$, the underworld river-god or flood from which all earthly rivers were thought to flow; a name frequently found at Mari. E. A. Speiser, ${ }^{7}$ on the other hand, has produced fresh reasons for supporting the better-known derivation of 7 from $e d \hat{u}$, which the Chicago Assyrian Dictionary ${ }^{8}$ defines as 'onrush of water, high water'. The occurrences of this word emphasize that it speaks of water in overwhelming quantity. E.g. in an inscription of Esarhaddon the terms 'a huge flood, a very Deluge, [which] overflowed and inundated the city [of Babylon]'9 are companion expressions to the phrase 'a raging $e d \hat{u}$ ', and in maritime contexts the word indicates mountainous seas. If either of these words, id or $e d \hat{u}$, is thought to be cognate with the Hebrew $7 x$, it gives the impression of a great and dynamic body of water.

2. At this point however the question whether verses 5 and 6 describe a dry world or a wet one becomes acute. Whichever

3. Fob, Anchor Bible, Doubleday, New York (1965) in loc.

4. $7 B L 57$ (1938) 231; 58 (1939) 102.

5. $R B$ I6 (1907) 274 .

6. $Z A W(\mathrm{I} 92 \mathrm{I}) 28 \mathrm{If}$.

7. BASOR I40 (1955) 9-II.

8. The Assyrian Dictionary, Oriental Institute, Chicago (1958) IV, 35-36.

9. Ibid. citing R. Borger, Die Inschriften Asarhaddons Königs von Assyrien, Graz (1956) 14, Ep. 7:39. 
way we translate $7 x$, the statement of verse 6 remains, that 'the whole face of the ground' was 'watered' by it, and the force of the rainless verse 5 seems hard to determine. The difficulty is reflected in the variety of interpretations that have been put forward.

F. Delitzsch ${ }^{10}$ cuts the knot by making verse 6 describe a series of events subsequent to verse 5 , in spite of the apparently circumstantial construction ואד יעלה, which he regards as introducing a new event that is going to be repeated. But he produces no parallel to this construction. More recently H. C. Leupold ${ }^{11}$ tries to circumvent the difficulty by the formula 'so a mist kept rising ... .', but he treats it as a subsequent development. $C$. T. Fritsch ${ }^{12}$ also, although he does not discuss the syntax, seems to assume the same.

Some writers try to reconcile the two verses by taking the $7 *$ to fulfil a different function from that of the rain. $S . R$. Driver $^{13}$ somewhat lamely suggests that it 'at least prepared the soil for the subsequent growth of vegetation', and $H$. Gunkel $^{14}$ has had many supporters (but also many critics) of his view that its supposed function was simply to wet the clay for the divine Potter. U. Cassuto, ${ }^{15}$ as we have seen, considered that until the Fall God used inundations, like those of the Nile, to water the earth, and only subjected man to the unpredictability of rainfall when his sin had made the discipline advisable. But this leaves the explanatory $5 \mathrm{~b}$ virtually unrelated to $5 \mathrm{a}$.

It was only to be expected therefore that various scholars would find the two verses incompatible, and deduce from this either a disturbed sequence or a composite narrative. For example, $C$. A. Simpson ${ }^{16}$ follows $O$. Eissfeld ${ }^{17}$ in making verse 6 follow verse 8 , so that the ' Eden. He further makes $5^{b \alpha}$ a gloss on the $7 \times$ of 6 , and $5^{b} \beta$

10. New Commentary on Genesis, T. \& T. Clark, Edinburgh ( I888) I, I I 7 .

11. Exposition of Genesis, Baker, Grand Rapids (1953) I, I 3 .

12. Genesis, Layman's Bible Commentaries, SCM, London (1960) 28.

13. Genesis ${ }^{8}$, Westminster Commentaries, Methuen, London (I9I I) 37.

I4. Genesis ${ }^{2}$, Vandenhoeck \& Ruprecht, Göttingen (I902) 5 .

15. Op. cit. ro4.

16. Interpreter's Bible, Abingdon Press, New York (1952) I, 493.

I 7. Hexateuch-Synopse, J. C. Hinrichs, Leipzig (r922) 255, cited by Simpson. 
an insertion in defence of farming to soften the impact of $3: 23$. Again, Gunkel ${ }^{18}$ divided chapters 2 and 3 between two interwoven Yahwistic sources, $\mathrm{Jj}$ and $\mathrm{Je}$, and $\mathcal{F}$. Meinhold ${ }^{19}$ followed this up with an elaborate contrast between (in one tradition) the fruit-eating first man (whom he names Cain) for whom the $7 \times$ watered the garden, and (in the other tradition) the soilcultivating Adam whose creation is anticipated in verse 5 . Another and more fundamental conflict between the $7 x$ and the rest of the story is implied by Gunkel's observation, echoed by many subsequent writers, that this element in the primeval scene is not said to be of Yahweh's making. Those who detect in the תהום $1: 2$ a fragment of unabsorbed mythology or calculated dissonance are therefore encouraged to find a similar trace here.

3. I suggest that the difficulty of this pair of verses is magnified by the failure to read them as a single statement moving to its full clarification in verse 6 ; also by a similar failure to hold together chapters $I$ and 2. Verses 5 and 6 are a twofold expansion of $4 \mathrm{~b}$, by which the bare phrase 'In the day that the Lord God made earth and heaven' is given specific content. About this opening stage of creation the reader is instructed first negatively, in the "not yet ... not yet ... not ... and ... none' of verse 5, an approach which starts from the known world and strips it of its chief familiar features. With his mind cleared of its ordinary presuppositions the reader should now be ready for the positive statement, however strange a scene it will depict; and this follows in verse 6 . It is, I suggest, none other than the scene presented in different terms in $I: 2:$ the unrelieved expanse of waters. The fact that rain is still unknown is therefore no sign of drought, but of the state of saturation that preceded the dividing of the waters on the

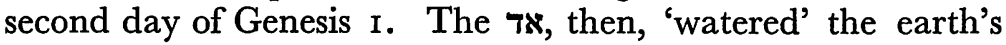
surface in the sense of inundating it-for השקה can denote any degree of watering. According to its context it is either beneficial, as in verse 10, or overwhelming, as in e.g. Ezekiel $32: 6$ ('even to the mountains').

18. Op. cit. $2 \mathrm{I}-24$, acknowledging his debt to $\mathrm{K}$. Budde.

19. Die Erzählung vom Paradies und Sündenfall, $B Z A W$ (1920) 122-131. 
So the two pictures of chapters $I$ and 2, so differently portrayed, complement one another, the present verse speaking in dynamic terms of the $7 \times$ surging up repeatedly, somewhat as in Job 38:8 where the sea 'burst forth from the womb'; while another aspect of the scene, as noted in the next verse of Job ('when I made clouds its garment, and thick darkness its swaddling band'), is presented in Genesis $\mathrm{I}: 2$. Incidentally, both aspects find expression in some modern reconstructions of the early situation; and while it is right to take only provisional notice of scientific hypotheses, they are of value in controlling our fantasies and in reminding us that Genesis $I$ and 2 are concerned with our actual planet. To quote a fairly representative view, Sir Harold Jeffreys argues that the water we now possess was originally 'in solution inside the Earth', from which it was 'extruded in the form of steam' as the earth cooled, forming a 'dense' and 'very opaque' atmosphere which included 'an appreciable fraction of the present ocean' ${ }^{20}$ It is at least interesting that both the rising up of the waters, which is a feature of chapter 2, and the darkness noted in chapter I, are currently postulated independently of holy Writ.

Returning to our context, we may paraphrase it somewhat as follows: 'When God made the earth and sky these were not initially at all as we know them now. Not even the wild growth existed on earth, still less the cultivated crops. Even the familiar heaven with its clouds and rainfall was not yet in evidence. On the contrary, the whole earth was inundated by waters that welled up again and again from within it.'

One question remains, and its very simplicity gives it force, namely, Why are these verses so widely misunderstood, if they are really speaking of a flooded world? In reply, I suggest that if one went straight to verse 6 one would not fail to be reminded of $\mathrm{I}: 2$; but verse 5 stands before it in order to introduce (although negatively) the main elements of the whole Paradise story. As Gunkel has pointed out, the narrative is carefully knit together by, amongst other things, the triple motif, God, Man, Soil. ${ }^{21}$ The two aspects of man, as a creature of God and

20. The Earth 4 , Cambridge University Press (1959) 285, 29 r. 
of the ground, are prominent throughout the account. From the earth he derives his body, as do all living things; through it he will enjoy God's bounty and exercise his abilities ('to dress it and to keep it'), and in terms of it and its produce he will make his crucial choice to serve God or defy Him. As the story ends, it is again the soil that is made the means of his discipline as a sinner. These dominant features of the story are anticipated in verse 5 , with man placed in his true context of heaven and earth, as if to say, 'The primeval world is only an introduction. Take note of it in terms of what it lacked, of the "not yet", and learn how radically God was to prepare for man and his probation. When these things are in being, and man set down among them, then the story of this world will have truly begun.'

21. Op. cit. $2 \mathrm{r}$.

(C) I966 D. KIDNER 